\title{
UNDERSTANDING PAK-CHINA RELATIONS THROUGH CPEC: GEOSTRATEGIC IMPLICATIONS FOR SOUTH ASIA
}

\author{
Iftkhar Ali* \\ Imran Ali Noonari ${ }^{+}$ \\ Pervaiz Ali Mahesar $\ddagger$
}

\begin{abstract}
In the prevailing geopolitical environment, China Pakistan Economic Corridor (CPEC) is the new addition with hopes of exploring new horizons in economic cooperation and expected to have regional and global geopolitical implications. Strategic thinkers, policy-makers, and scholars have heralded CPEC as a magnificent trade and investment project of future geopolitics. Yet many analysts have raised their eyebrows about the USA and Chinese competition ultimately seeking robust security and economic strategy by China and Pakistan to avoid Indo-US designs. The objective of this study is to focus on the all-weather relationship, which China and Pakistan are enjoying with shared goals and interests in the region. This article focuses on the China and Pakistan relations while keeping in mind the emerging strategic partnership of the United States with Pakistan's belligerent neighbour India through a neo-realistic perspective focused on structure and anarchy in the international political system.
\end{abstract}

Keywords: Strategic stability, Pakistan-China relations, neorealism, Gwadar

\section{INTRODUCTION}

China is now connecting the 'inner crescent' through CPEC and Silk Road Economic Belt (SREB) whereas the 'outer crescent' will be

\footnotetext{
*Assistant Professor, Department of International Relations, Karakoram International University Gilgit. Email: iftikhar.ir@kiu.edu.pk ${ }^{+}$Assistant Professor, Department of Political Science, University of Sindh. Email: imran.noonari@usindh.edu.pk (Corresponding author)

¥Assistant Professor, Department of Political Science, University of Sindh. Email: pervaiz_mahesar@yahoo.com
} 
connected through Maritime Silk Road (MSR). It is being considered as Chinese Grand Strategy with its apparent connections with Suz Tzu's acme of skills for winning without a fight. It has gained the greatest attention of geopolitical analysts, academicians, and policymakers since its official pronouncement in 2015. Simultaneously, the strategic analysts are also pondering about the possibility of 'Thucydides Trap' for rising China through Belt and Road Initiative (BRI) and global hegemon USA through its policy of Asia Pivot. Allison (2017) believed both are destined to war unless a party blinks the eye.

This shift in both Chinese and US policies as well as global structure makes it an enduring task for scholars to study the possibility of conflict and cooperation as argued by realists and neoliberals. Neoliberalism also supports the realist notion that the absence of central government makes it difficult for states to cooperate and create an opportunity to advance their interests unilaterally (Jervis, 1999). What would be the impact of CPEC on the geostrategic and geopolitical environment of South Asia? Why USA and India would perceive it as a challenge rather than an opportunity? Would it play the role of stabilizer or further widen the cleavages of instability? To understand the phenomena, a detailed inquiry is needed about the history of Sino-Pakistan relations, CPEC, and the current geopolitical structure of South Asia.

\section{SINO-PAKISTAN RELATIONS}

The relationship between the people of China and Pakistan is as old as the world-renown Silk Road. However, the diplomatic relations between China and Pakistan started when Pakistan became the first Muslim and third non-Communist country to recognize the People's Republic of China (PRC) in 1951 and both established their diplomatic offices in Karachi and Beijing. 'Taller than mountains and deeper than oceans' is the term used to state the friendship between the two countries, which is a model for countries with different socio- 
economic and cultural identities making fruitful successes in the fields of defence, economy, trade, culture, and industrial development. Since both countries share a common history of colonial exploitations, struggle against global hegemonic powers, and safeguarding sovereignty and national interests, and this unprecedented relationship is time tested with geopolitical and strategic aspects as its hallmark (Ghengli, 1996).

On the political dimension, Pakistan has extended its enormous and valuable support to China on a wide range of issues. It was Pakistan that bridged the relations between the USA and China and helped President Nixon's visit to China in 1970. In the repercussions of the 1989 Tiananmen Square incident, which is commonly known as the June Fourth Incident, China suffered at the international diplomatic and political fronts and subsequently many countries had boycotted Chinese National Day celebrations, Pakistan stood with China and sent a representation led by Speaker of Pakistan's National Assembly. Pakistan was also the first country to receive Chinese premier Li Peng in November 1989. During his visit to Islamabad, Premier Li Peng expressed his gratitude for Pakistan and said 'at a time when China is suffering some temporary difficulties, we see clearly who our true friends are and who are not' (Garver, 1992).

The endurance and persistence of close relations are traceable to geostrategic and geopolitical realities resultantly China stood steadfastly at the side of Pakistan with its decisive moral and material support during the wars of 1965 and 1971 against India. In 1972, Chinese Veto to Bangladesh's entry into the UN played an important role in the repatriation of Pakistani prisoners of war (Ali, 1974). In 1976, both countries signed an agreement to cooperate in seven areas including industrial standards, oil exploration, oceanography, and aquaculture. As an extension of this agreement, China signed an agreement with Pakistan to cooperate in the fields of nuclear technology in late 1986, which gave a new dimension to the existing relationship. It was the time when Pakistan was deprived of nuclear 
technology needed for the country's economic development (Siddiqui, 1986). Pakistan started to work on the development of liquid-fuelled missiles during the mid-1980s and came up with the results of the Hatf-1 and Hatf-2 programs with Chinese assistance in the field.

To further the strategic collaboration between the two, Pakistan's ministry of defence and Chinese ordinance company NORINCO developed the state-of-the-art main battle tank Al-Khalid in 2001, which is considered to be lethal and powerful in terms of its mobility and survivability. Other components of entente include a robust weapon program of mutual interest that ranges from developing Pakistan's missile systems to the development of F-7P, MiG21, and JF-17 Thunder. Besides Chinese development of Pakistan's deep-sea port at Gwadar, China-Pakistan Free Trade Agreement, F-22P Frigates coming into service with the Pakistan Navy and handing over of Gwadar port management to Chinese Overseas Port Holdings were the significant developments by 2013.

To improve the communication links between the two, work started for the widening and up-gradation of Karakoram Highway $(\mathrm{KKH})$ in 2008 however due to a landslide in Atta Abad village of district Hunza blocked the River Hunza, which spilled over to $19 \mathrm{~km}$ on $\mathrm{KKH}$ and converted it into a lake on the site. This blockade not only displaced some 400 families, but it also stranded the communities living along the Chinese border in the upper Gojal area of Hunza district, it also gave a setback of worth $\$ 8.7$ billion to the land trade through $\mathrm{KKH}$. Temporary communication was made possible through boats but in December 2010, Pakistan and China signed a $\$ 275$ million project to repair the damaged portion of the $\mathrm{KKH}$. However, in 2011 NHA and CRBC signed a contract of $\$ 25$ billion for the realignment of the $\mathrm{KKH}$ through tunnels. Chinese Roads and Bridges Corporation (CRBC) completed the construction work in a short period of three years. However, after the Chinese takeover of Gwadar port by China from the Singapore Port Authority, the 
Chinese premier visited Pakistan and formally proposed a corridor to connect Kashgar with Gwadar through a 'network of roads, proposed railway tracks, an energy pipeline, and fibre optics' (Ali, 2017).

\section{CHINA PAKISTAN ECONOMIC CORRIDOR}

The idea to establish a corridor linking China with Arabian Gulf through Pakistan dates to President Musharraf's visit to China on February 19-23, 2006. At the invitation of Chinese President Hu Jintao, President Musharraf visited China where he expressed his interest in Pakistan to serve as a conduit for China's energy and economic needs. After being briefed about President Hu's vision of linking China with the Gulf through Pakistan, President Musharraf was quoted as he looks forward to 'materializing cooperation in the energy sector where establishment of oil refineries, oil storage facilities and gas pipelines stand out' (Zeb, 2012, p. 153).

Chinese President Hu Jintao visited Pakistan in November 2006 and signed Free Trade Agreement (FTA) and Five-Year Development Program on Trade and Economic Cooperation with Pakistan. As an essential component of the Five years development program, Pakistan proposed to establish Pak-China Trade, Transport, Energy, and Industrial Corridor. Whereas, after taking oath as President of Pakistan, Asif Ali Zardari went an extra mile in consolidating the existing relations between the two by visiting China four times in a row during 2008-09 (Gillani, 2009). During May 22-23, 2013 Chinese Premier visited Pakistan proposed the establishment of CPEC, and decided with his Pakistani counterpart to jointly prepare a long-term plan on it. However, in April 2015 during his visit to Pakistan, President Xi formally announced the launch of the China-Pakistan Economic Corridor (CPEC) with 51 agreements and MoUs worth $\$ 46$ billion (Khan, 2017).

President Xi Jinping announced the launch of the historic One Belt One Road Initiative now commonly known as BRI. It is a twopronged Chinese strategy collectively comprised of the Maritime Silk 
Road Initiative (MSRI) and Silk Road Economic Belt (SREB). It is focused on trade and investment-related projects considered to be the harbinger of the future of geopolitical flows to opening up and marching westwards through landlocked countries (SREB) and waters (MSRI) for the development of a vast network of infrastructure connecting Eurasia, East Asia, South Asia, Middle East, Central Asia and Africa (Xie, 2015).

To understand the CPEC, it is important to first understand the characteristics that symbolize an economic corridor. Generally, an economic corridor comprises (i) small geographical space with a transport highway such as road, rail, or canal; (ii) bilateral strategic initiatives connecting different nodes at borders; and (iii) physical planning to achieve positive benefits of the infrastructural development (Iyengar, 2014). The CPEC is divided into three stages of development, which include the Early Harvest Projects (20152020), Medium-Term Projects (2021-2025), and Long-Term-Projects (2026-2030). To facilitate the mechanism of cooperation between China and Pakistan, a ministerial-level Joint Cooperation Committee (JCC) has been set up under which there are seven Joint Working Groups (JWC) working on planning, energy, infrastructure, Gwadar Port, transportation, industrial, socio-economic development and international cooperation. For communicating and coordinating on different projects under CPEC, two secretariats have been established in the Ministry of Planning, Development, and Reforms (PDR) of Pakistan and the National Development and Reforms Commission (NDRC) of China. JCC has conducted eight meetings to review the progress of CPEC and the last meeting was held in Beijing on December 20, 2018, whereby different plans were finalized with consensus. The overall projects included in Early Harvest Projects, Medium-Term and Long-Term are further classified into four categories. 


\section{Energy}

As an offshoot of BRI, CPEC has multiple prospects for both Pakistan and China. It will provide China the shortest and economical route to connect with Middle Eastern and African countries upon which it heavily depends for its energy requirements. After being fully functional, CPEC will transport oil from the Middle East to China within 10 days as compared to 35- 45 days through other sea routes subject to conditions. Since $75 \%$ of Chinese trade is being conducted through the Indian Ocean which is prone to pirates and US and Indian monitoring, CPEC will provide a safer and shorter route by lessening the distance to more than $10000 \mathrm{~km}$ from China to Middle East(Rao Qasim Idrees, 2018).

China is currently importing nearly 75-80 per cent of its oil imports from the Middle East through the Malacca Straits that separate Malaysia and Indonesia with Singapore, which is the shortest possible waterway between the Pacific and the Indian Ocean, which carries 25 per cent of global trade. Being inferior to Americans in sea power, the Chinese fear any disruption of free energy supplies through Malacca Straights could derail its economic progress(Storey, 2006). Being the world's second-largest consumer and importer China has security concerns about its current transportation of nearly $6.2 \mathrm{mb} / \mathrm{d}$ of crude through a region, which it does not immediately neighbor. Although China is working on a $\$ 28$ billion Thai Canal Project to counter the 'Malacca Dilemma', which will connect the South China Sea to the Andaman Sea. This project is a part of MSRI, represents Chinese efforts to secure a shorter and safer naval transportation of its energy requirements and reduce its dependencies (Menon, 2018). However, in terms of safety, security, and uninterrupted timely delivery of imports, the Thai Canal Project is not providing equal opportunities for China as compared to CPEC, which directly connects Gwadar to Chinese Kashgar. This route has no hostile elements throughout its way from China to the Arabian Sea reducing Chinese security and time constraints. The increase of 
Chinese national oil companies in oil exploration in the Middle East and Africa reflects the Chinese consciousness about its energy requirements. Chen Shaofeng posits it important to regard energy security as a condition in which continuous and stable oil supplies are available to satisfy domestic oil demands to ensure national survival, social stability, and economic development (2011).

Chinese oil imports have sweeping increase from 4172 to 10241 thousand barrels daily. In nutshell, energy consumption in China rose by 3.1 per cent, which was the largest growth market for energy during the last seventeen years consecutively, however, the Chinese production growth rate was -3.8 per cent per annum. It is expected that by 2020, China will outpace the USA in net oil imports and the Chinese consumption is alone equating to the total consumption of Europe. Chinese governments are aware of these challenges and have activated their national oil companies to formulate resolute internationalization strategies (Dannreuther, 2011).

Keeping in view of the growing consumption demands of the Chinese economy, CPEC provides an economical, securer, and one-link route from the Arabian Sea to China. CPEC is also designed to meet the energy requirements of Pakistan, which are the bottleneck constraint of Pakistan's domestic needs, as well as the economic and industrial growth. Out of 19 Early Harvesting Projects, 11 are energy projects and five have been completed with a record speed of construction. Once all energy projects are completed, it will add a total of 11000 MW of electricity to the national grid(Weidong, 2017). These energy projects were supplemented with the agreement of CPEC and signed on November 8, 2014, which have been termed as 'Energy Cooperation Agreement' (ECA) based on hydro, coal, wind, and solar energy.

The completion of the above projects will help Pakistan in dealing with its significant energy shortfall and if these projects are completed as envisaged by the planners of CPEC then it will have a cornucopia 
of advantages to Pakistan's economy and industry. Overall the project has inalienable benefits for both China and Pakistan. On one side providing China an opportunity to convert its less-developed western regions Xinjiang and Tibet into an energy corridor by integrating them with the mainstream Chinese economy and providing secure access to the Arabian Gulf bypassing the Straits of Malacca. On the other side, it provides Pakistan an opportunity to receive much-needed infrastructure and a reliable energy supply (Ingle, 2018).

\section{Infrastructure}

CPEC not only deals with the energy requirements but will also facilitate the infrastructural development of Pakistan. The infrastructural development through CPEC will create job and business opportunities and reduce unemployment. The project will connect the main cities of Pakistan through road links, motorways, railway tracks, and fibre optic, which will further integrate Pakistan with China and the regional countries.

The above-mentioned projects are aimed to serve for inter-provincial connectivity and link Gwadar with Chinese Xingjian. According to the Center of Excellence for CPEC working paper, 67 per cent allocation has been made on roads whereas rail and optical fibre has 30 per cent and 3 per cent respective shares in infrastructural development. Out of 51580 total labour force employed in the infrastructure development projects, 93 per cent labour was domestically employed from Pakistan whereas 7 per cent skilled labour was Chinese (Employment Outlook of CPEC: A Meta-Analysis, 2018). China Pakistan Economic Corridor will develop the infrastructure of Pakistan and link it with the region through BRI and proved to be the largest platform of finance, trade, and investment coordination. Once the infrastructure as proposed through CPEC is developed and completed, it will provide, road and rail communication to Afghanistan, Iran, and Central Asia, which will be having geopolitical implications for Pakistan, China, and the region. 


\section{Gwadar Port}

Gwadar is situated on the shores of the Arabian Sea in the southwestern coast of Baluchistan which remained under the possession of Oman from 1783 to September 8, 1958, till Pakistan formally purchased it. In 1882, British explorer, geographer, an officer of British Indian Intelligence, Sir Charles MacGregor reported about the importance of Gwadar for a modern port (Nicolini, 2002). However, due to lack of resources and market feasibility, this small village could not gain much attention till March 2002, when Pakistan signed an agreement of \$248 million with China Harbour Company to build Gwadar port Phase-I. Later in October 2003, the Gwadar Development Authority was established (Ahmed, 2016). In terms of Chinese investments in Pakistan, Gwadar has become the jewel in the crown of Beijing's development projects especially CPEC and BRI's Maritime Silk Road Initiative linking Pakistan with BRI vis-a-vis China to Europe and beyond (Calabrese, 2015).

Gwadar is being expected to play a very significant role in Pakistan and China relations in particular and their relations with the Middle East, Africa, Europe, and Central Asia in general since it will be playing a pivotal role in converging both SREB and MSRI of the BRI. Presently it is being developed as a commercial seaport, which can also facilitate PLA Navy (PLAN) in the future. Both China and Pakistan are concerned with the security of Gwadar and to reinforce the defence, China is expected to provide eight diesel-powered conventionally armed attack type 039A and 041A submarines through a US\$ 5 billion deal. The first four out of eight subs will be delivered by 2023 whereas the remaining four will be assembled in Submarine Rebuild Complex (SRC) Ormara, Karachi where Pakistan is also engaged in building two types of submarines under Chinese licensed assistance(Gady, 2016). No doubt, these strategic engagements with China will increase Pakistan's sea-based antisubmarine, anti-surface warfare, and intelligence gathering leading to second-strike nuclear deterrence capability. These arsenals will 
complicate Indian naval superiority and will result in China-India maritime security competition in the Indian Ocean(Rakisits, 2015).

There is a possibility that Gwadar to be developed as an energy port since projects like the Iran-Pakistan gas pipeline may go through Gwadar into Xinjiang (Khan, 2011). Furthermore, China has also constructed the Makran Coastal Highway to link Gwadar with Karachi and more recently, Pakistan has started the construction of its largest airport in Gwadar under US\$ 230 million Chinese Assistance Grant under BRI. This project will be completed in three years and it will be the second facility in Pakistan to cater to the largest passenger aircraft like Airbus A380. This airport spread over an area of 4300 acres will be equipped with a modern terminal building having a capacity of handling 30000 tons of cargo per year (Ahmed, 2019).

Given the significance of Gwadar, its affiliated projects, and regional conflicts, there is a possibility of and logic to expect adversaries to create hurdles. The possibility for conflicts like situations between Gwadar and Iranian port Chabahar is diminished with the increasing cooperation and the Iranian desire to become part of CPEC in the future has further increased the prospects of regional connectivity and prosperity (Abbas, 2016). However, scholars, analysts, and strategic experts have raised their eyebrows about Indian efforts to destabilize CPEC through Afghanistan and its involvement in Baluchistan through the Baluch nationalist discourse (Iqbal, 2015).

\section{GEOSTRATEGIC IMPLICATIONS FOR SOUTH ASIA}

Where CPEC has opened a window of opportunities for Pakistan, China, and the regional countries, it will also lead to the possible contestation of India and the United States. Though China may not fall into prey to the Thucydides Trap, as cautioned by Allison Graham, that may lead to any confrontation between the US and China. However, a new Cold War has commenced whereby India and Pakistan are to play the lead role of allies for the US and China 
respectively. The US grand strategy of 'Asia Pivot', which was later renamed as 'rebalancing' elucidates US fears of rising China that forced the US to shift their focus from the Middle East to Asia-Pacific with greater attention and focus on Indian and the Pacific Ocean. Since 'pivot' is a vague representation and no less ambiguous than the symbol of national security (Wolfers, 1952) and it means different things to different people. Neo-realist, constructivists, and liberals see the symbol of 'pivot' in different connotations. For neo-realists like John Mearsheimer, the primary goal of great power is to prevent the challenger in its own region and great power that dominates more than one region. Chinese rise has similar tendencies in the current global geopolitical structure (Mearsheimer, 2001). In 2011, when Obama administration's strategy of Asia Pivot got attention, Secretary of the State Hillary Clinton wished-for pivot or rebalancing strategy to rest upon diplomacy, economy, and security seeking the US at the center of the region stretched across Indian and Pacific Oceans (Clinton, 2011). Theoretically, neo-realist strategies are based on propositions of 'China containment,' liberals emphasize 'peaceful evolution through trade and investment,' and neo-conservatives aim 'pre-emptive military confrontations' (Sultan, 2013).

In such an anarchic world as portrayed by neorealists, if CPEC is completed as envisioned and connected with BRI while India and the US remain inactive, China and Pakistan may gain a significant defensive advantage at substantial financial cost. If India-US cooperation leads to creating hurdles for the CPEC, while China and Pakistan remain inactive, Indo-US alliance gains a significant offensive advantage at significant financial cost. If China-Pakistan cooperation foils Indo-US designs to obstruct the CPEC, it will neutralize the defensive and offensive advantages; in other words, strategic stability will prevail in South Asia. However, it is expected and envisioned that Pakistan and China will choose to confirm their policies and avail the opportunities offered by the structural changes in the international political system. 
The strategic cooperation between China and Pakistan has significant implications for the strategic stability in the region. Since Pakistan's threat perception is shaped by the limitation of its resources and based on its geographical characteristics, troubled clash over Kashmir, the military capabilities and intentions of a hostile neighbour, and its continuous struggle to maintain an acceptable conventional military balance with India. Whereas, Indian threat perception is coupled with Pakistan and China originated from its border disputes. Though the relations between China and India have improved to a great deal Indian strategic thinkers believe that it maintains an all-weather friendship with Pakistan, which will use force against India over Kashmir. Similarly, Pakistan is concerned with the Indian strategic partnership with the United States, which is strengthening Indian defence technology against China making it hard for Pakistan to keep the peace in the arms race against India.

Although liberals may assume that CPEC, as well as Indo-US cooperation, may increase connectivity and economic interdependence, but one cannot deny the realistic perspective that many of the means through which one state increases its security will decrease the security of other states ultimately giving a gloomy picture of anarchy and security dilemma. In case of South Asia, if Pakistan gains invulnerability by improving its infrastructure and power bases, anarchy and security dilemma suggests that India will perceive it as a problem and will consider Pakistani improvements in security a base from which it can exploit India. The geopolitics in the region and the structure of the international system forces Pakistan and China to further strengthen their relations as per illustrations of neorealism (Kasi, 2017).

Both India and Pakistan have developed their security models to deal with their threat perception, which can be translated into different strategic dilemmas. Conventionally India enjoys superiority over Pakistan in terms of Army, Air Force, and Navy, therefore; Indian security model is premised on dominance strategies. Whereas 
Pakistan's strategy is based on the 'survival in a hostile environment' (Matinuddin, 2002) which forces Pakistan to build its warding-of mechanisms (Cheema, 2008), nuclear weapons have played an important role in the maintenance of strategic stability. The situation best described by Stephen P Cohen, that India cannot make peace with Pakistan and Pakistan cannot make war against India and the tension between the two may continue with further perfection (Cohen, 2013).

Keeping in view of security challenges, along CPEC starting from the Chinese border at Khunjrab to Gwadar, Pakistan has established Special Security Division (SSD) headed by a Major General and comprised of 9 infantry battalions and 6 wings of civilian armed forces. SSD has become operational and being deployed for the security of Chinese nationals across the country on each project site under CPEC. Whereas, to protect the Gwadar City and the port, Gwadar Security Task Force (GSTF) has been mobilized under the command of a brigadier (Haider, 2015). The war in Afghanistan and the situation in Indian occupied Kashmir have provided space for external hostile elements to impede the development of CPEC. India has opposed CPEC and considers it passes through the disputed territory of Gilgit-Baltistan. Indian Prime Minister Narendra Modi's reference of Baluchistan and Gilgit during his 2016 Independence Day speech was a blatant attempt towards destabilizing CPEC. Modi stated that 'the people of Baluchistan, the people of Gilgit, the people of Pakistan-occupied Kashmir have thanked me in such a manner, from places that I have never been and never had a chance to meet, they have sent wishes to the people of India and thanked us, and I am grateful to them' (Dawn, 2016). Similarly, the US also threw its weight behind Indian opposition to CPEC in October 2017.

Pakistan's Baluchistan and China's Xinjiang province share similar characteristics in terms of problems and resources. At the gateway of CPEC is Pakistan administered Gilgit-Baltistan, which India and America called disputed, has an unresolved constitutional problem at 
the exit point is Baluchistan where separatist movements and terrorist groups like Tehrik-i-Taliban Pakistan (TTP), Lashkar-e-Jhangvi (LeJ), and ISIS are continuously posing threats to the security of the CPEC. Pakistan has arrested a serving Indian intelligence officer Kulbhashan Yadav from Baluchistan who has confessed about his deployment to impede the developments of CPEC (Mahesar, 2017).

\section{CONCLUSION}

The launch of BRI's Maritime Silk Road Initiative (MSRI) and regional connectivity envisaged under CPEC has strategic implications arising out of fears in US and Indian policymakers due to Chinese and Pakistani rise against the global and regional hegemons respectively. Although Pakistan has bolstered its security in Baluchistan, Waziristan, and Gilgit-Baltistan defeating the terrorists and uprooting terror networks from its soil, there is still a lot more to counter the hostile elements that seek to destabilize the region ultimately posing threats to CPEC. Since CPEC is the jewel of the crown in BRI and Pakistan plays a vital role in materializing Chinese grand strategy, the US is boosting its ties with India through its strategic partnership, nuclear deals, and provision of military hardware and technology compels Pakistan to ensure its deterrence credibility against India. US policy in the region, to prop India up as a counterweight to China through cooperation in nuclear, missile, and maritime technologies, can be counterbalanced by Chinese assistance to Pakistan in similar fields.

CPEC and BRI have provided Pakistan to play the role of South Asian connecter between the pivot and the outer crescent in the geopolitics of the world. CPEC has the potential to provide opportunities for the whole region including Iran, Afghanistan, India, Middle East, and Central Asia. However, the Chinese rise, economic achievements, their opening to the world through different corridors and networks indicate the changing global structure and widen the cleavages of anarchy, which collectively culminates into the greater significance of 
South Asia in the future.

\section{REFERENCES}

Abbas, S. S. (2016, September 22). Iran wants to be part of CPEC. Dawn. Retrieved from https://www.dawn.com/news/1285404

Ahmed, A. (2019, March 31). Pakistan's Gwadar international airport will be the largest in the country. Gulf News. Retrieved from https://gulfnews.com/world/asia/pakistan/pakistans-gwadarinternational-airport-will-be-the-largest-in-the-country1.63033953

Ahmed, A. (2016). Gwadar: A historical kaleidoscope. Policy Perspectives, 13(2), 149-166.

Akhtar, A. S. (2007). Balochistan versus Pakistan. Economic and Political Weekly, 42(45-46), 73-79.

Ali, G. (2017). China-Pakistan relations: A historical analysis. Karachi: Oxford.

Ali, I. (2017, November 2). Chinese dream of National Rejuvenation. Pakistan Observer. Retried from https://pakobserver.net/ chinese-dream-national-rejuvenation/

Ali, M. (1974). Pakistan-China relations. Pakistan Horizon, 27(2), 52-56.

Allisan, G. (2017). Destined for war: Can America and China escape Thucydides's Trap? New York: Houghton Mifflin Harcourt Publishing.

Attiq-ur-Rehman. (2018). Maritime politics in South Asia and naval compulsions of CPEC for Pakistan. Policy Perspectives, 15(1), 81-94.

Banderjee-Guha, S. (2011). Post-September 11 Indo-US strategic ties: Locating power and hegemony. The Geographical Journal, 177(3), 223-227. 
Brewster, D. (2010). The Australia-India Security Declaration the Quadrilateral Redux. Security Challenges, 6(1), 1-9.

Business Recorder. (2013, May 23). Pakistan-China relations timeline. Retrieved from https:/fp.brecorder.com/2013/05/ 201305231188551/

Calabrese, J. (2015). Balancing on 'the Fulcrum of Asia': China's Pakistan strategy. Indian Journal of Asian Affairs, 28(2), 1-20.

Clinton, H. (2011). America's Pacific century. Foreign Affairs, 189(1), 56-63.

Dannreuther, R. (2011). China and global oil: Vulnerability and opportunity. International Affairs, 87(6), 1345-1364.

Dawn. (2016, August 2015). People of Balochistan, Kashmir thanked me: Modi on India's Independence Day. Retrieved from https://www.dawn.com/news/1277670

Farooq, S., Kazmi, S., \& Javed, J. (2018). Indo-US strategic partnership: Implications for Pakistan, Policy Perspectives, 15(1), 3-20.

Gady, F. S. (2016, August 30). China to supply Pakistan with 8 New Stealth Attack Submarines by 2028. The Diplomat. Retrieved from https://thediplomat.com/2016/08/china-to-supplypakistan-with-8-new-stealth-attack-submarines-by-2028/

Garver, J. W. (1992). China and South Asia. The Annals of the American Academy of Political and Social Science, 519, 67-85.

Ghengli, Z. (1996). China-Pakistan relations and situation in South Asia. Pakistan Horizon, 49(3), 11-15.

Gillani, S. N. (2009, August 27). Fourth visit to China. The Nation. Retrieved from https://nation.com.pk/27-Aug-2009/thefourth-visit-to-china

Haider, M. (2015, December 15). 17177 soldiers deployed for security of Chinese workers of CPEC. The News. Retrieved from https://www.thenews.com.pk/print/82009-17177-soldiers- 
deployed-for-security-of-Chinese-workers-of-CPEC

Hameed, R. (2017). Pakistan and China: Partnership, prospects and the course ahead. Policy Perspectives, 14(1), 3-22.

Golley, J., \& Ingel, A. (Eds.) (2018). The Belt and Road Initiative: How to win friends and influence. In J. Golley, \& L. Jaivin (Eds.) Prosperity (pp. 42-61). Canberra: ANU Press.

Idrees, R. Q. (2018). Energy cost saving and economic perspective of China Pakistan Economic Corridor, International Journal of Energy Economics and Policy, 8(6), 217-226.

Iqbal, K. (2015, April 27). Challenges to China-Pakistan cooperation. The Nation. Retrieved form https://nation.com.pk/27-Apr2015/challenges-to-china-pakistan-cooperation

Iyengar, P. D. (2014). Developing economic corridors in South Asia. Mandaluyong: Asian Development Bank.

Jervis, R. (1999). Realism, neoliberalism, and cooperation: Understanding the debate. International Security, 24(1), 42-63.

Khan, A. H. (2017, August 23). CPEC: Whose project is this? Business Recorder. Retrieved from https://fp.brecorder.com/2017 /08/20170823211718/

Khan, R. M. (2011). Pakistan-China relations: An overview. Pakistan Horizon 64(4), 11-28.

Mackindar, H. (1904). The geographical pivot of history. The Geographical Journal, XXIII(4), 421-444.

Mattis, J. (2017, October 4). On OBOR, US backs India. Times of India. Retrieved from https://timesofindia.indiatimes.com /world/us/on-obor-us-backs-india-says-it-crosses-disputedterritory/articleshow/60934571.cms

Mearsheimer, J. J. (2001). Tragedy of great power politics. New York: W.W. Norton. 
Menon, R. (2018, April 6). Thailand's Kra Canal: China's way around the Malacca Strait. The Diplomat. Retrieved from https://hediplomat.com/2018/04/thailands-kra-canal-chinasway-around-the-malacca-strait/

Ministry of Planning, Development \& Reforms. (2017). Long Term Plan for CPEC (2017 - 2030). Retrieved from https://www.pc.gov.pk/uploads/cpec/LTP.pdf

Montagnon, T. W. (1996, April 1). Sharp frosts still threaten China-US links. Financial Times, p. 5.

Neelis, J. (2011). Early Buddhist transmission and trade networks: Mobility and exchange within and beyond the North-western Borderlands of South Asia. Boston: Brill.

Nicolini, B. (2002). Historical and political links between Gwādar and Muscat from $19^{\text {th }}$ century testimonies. Proceedings of the Seminar for Arabian Studies (pp. 281-286). Edinburgh: Archaeopress Publishing Ltd.

Rakisits, C. (2015). A path to the sea: China's Pakistan plan. World Affairs, 178(3), 67-74.

Rippon, S. (1995). Asian subcontinent: Nuclear programmes in Pakistan, India. Fuel and Energy Abstract, 5(36), 340.

Pak-China. (2016, November 14). Trade through CPEC from Gwadar begins. Retrieved from http://pakchina.pk/trade-cpecgwadar-begins/

Shanglin, L. (2001). Pakistan-China relations. Pakistan Horizon, 54(3), 13-15.

Shaofeng, C. (2011). Has China's foreign energy quest enhanced its energy security? The China Quarterly, 207, 600-625.

Siddiqui, W. (1986). Sino-Pakistan nuclear Accord. Pakistan Horizon, 39(4), 53-59. 
Storey, I. (2006, April 12). China's 'Malacca Dilemma'. The Jamestown Foundation Global Research \& Analysis. Retrieved from https://jamestown.org/program/chinas-malacca-dilemma/

Sultan, B. (2013). US Asia Pivot Strategy: Implications for the regional states. Institute for Strategic Studies Research and Analysis (ISSRA) Papers, 135-150.

Weidong, S. (2017). Pakistan-China relations: CPEC and beyond. Policy Perspectives, 14(2), 3-12.

Wolfers, A. (1952). National Security as an ambiguous symbol. Political Science Quarterly, 67(4), 481-502.

Xie, X. C. M. (2015). Research on employment opportunities under the framework of CPEC. Proceedings of International Conference on CPEC (pp. 107-126). Lahore: GC University.

Zeb, R. (2012). Pakistan-China relations: Where they go from here? Center for Muslim States and Societies: Discussion Paper, 4558. 